\title{
Research on Improving the Ideological and Political Education of College Students Based on Campus Culture
}

\author{
Ling-ling ZHANG \\ Publicity Department of the Party Committee \\ Agricultural University of Hebei \\ Baoding,China
}

\begin{abstract}
Campus culture which has become a kind of potential education power is the effective carrier of ideological and political education in colleges and plays an important role in the development of ideological and political education. In the new situation, making full use of the aesthetic function of campus culture to realize the unity of the aesthetic education and ideological and political education can effectively carry out ideological and political education. So we can promote ideological and political education with the aesthetic image characteristics. Therefore, the ideological and political education can be promoted by the characteristics of aesthetic education such as figurativeness, emotion and potentiality.
\end{abstract}

Keywords: Campus culture; Aesthetic education; Ideological and political education

\section{INTRODUCTION}

The concept of "campus culture" was introduced in 1920s, and developed from 1950s to 1960s. Until the 1980s, this concept was independent among the social culture. At present, more consistent expression from the perspective of sociology, think that the campus culture is an important part of social culture, and is also a kind of subculture form which has its own characteristics. Moreover, campus culture is the refraction and reflection of social culture in the campus, is the campus communication bridge with the mediation of society. In this sense, college campus culture is an important symbol which is gradually formed in the process of its own long-term development, regards the teachers and students in colleges and universities as the main body, colleges as the creation space, campus spirit as the inner core, aesthetic education as the main direction, reflects the university teachers and students staff generally agree and adhere to follow the value orientation, mode of thinking and behavior criterion of social subculture. In addition, it reflects the characteristics, appearance and personality, which represents the spirit of the college ${ }^{[1]}$.

College campus culture form basically has the following three types:

(1) Material culture. It is in the process of development of college campus culture accumulated external materialized in the form of a general designation, including the campus natural environment and physical construction, such as teaching building, library, teaching, scientific research equipment, recreational activities, campus landscape, sculpture, tablet, etc.

(2) Spiritual culture. It is the soul and core of the construction of campus culture. The specific performance are the school motto, school spirit, teaching spirit and learning spirit. The school motto is the core content of campus culture spirit. School motto is the basic code of conduct and ethics which requires a vast number of teachers and students to abide. It is not only a reflection of school educational philosophy and the school spirit, but also the important content of the construction of campus culture.

(3) Institutional culture. It is the comprehensive reflection in the process of running colleges in the management idea, management system, management mode and management level. On the one hand, it puts the tangible 
system specification as the external form. On the other hand, it puts invisible values into the institution, including the teaching management institution, scientific research management institution, student management institution, and regulations of the logistics management institution and the implementation of the organization.

Campus culture form is various, and needs a certain carrier to express which called the carrier of campus culture. According to the loaded content, these carriers can be divided into four types. First is the academic cultural carrier, such as classroom, library, academic lecture hall, etc. Second is the promoting educational and cultural carrier, such as the school newspaper, the school radio station, publicity column, school rules, the school mental health guidance mechanism, etc. Third is the entertainment culture carrier, such as gymnasium, swimming pool, club (college student activity center), etc. Fourth is the practice skilled culture carrier, such as college students of public welfare activities, work-study, social practice, etc. Of course, with the development of the era, campus culture will be constantly updated. There will be accordingly with the new campus cultural carrier.

\section{The relationship between campus culture and ideological and political education}

Campus culture and ideological and political education are both the important part of university work, which objectively exist in the process of higher education. Campus culture and ideological and political education are the relatively independent systems, which respectively plays an irreplaceable role. Campus culture influences the value orientation of staff and students in the form of osmosis, way of thinking and behavior criterion. While the ideological and political education educate college students' ideological and political education and moral education with the ways of the infusion. But both are interdependent, mutual penetration, interaction, mutually influence ${ }^{[2]}$.

Firstly, the ideological and political education dominate the development direction of campus culture. The development of college campus culture should always be around the country's deployment and requirement to the ideological and political education in colleges and universities. The content should be corresponded to the theme of the ideological and political education, and serves for ideological and political education work, cultivate qualified socialist builders and successors of the service.

Secondly, the campus culture is an effective carrier of ideological and political education. Campus culture mainly reflects the strong ideological and political education functions from the following two aspects: One is the talent training guide function. The other is the thought behavior constraint specification function.

If the truly effective ideological and political education achieves a good effect on educatees, the single force-feeding ideological and political education is not enough. The campus culture factor must be fully considered, which can make the ideological and political education effect moistens everything silently. Only a noble, healthy campus culture can have positive effect on ideological and political education. The low-level and vulgar culture existed in the campus can only have negative effects on ideological and political education, and it will reduce, weaken or even offset the effect of ideological and political education. Therefore, in order to strengthen and improve ideological and political education, the construction of excellent campus culture must be strengthened.

\section{Strengthen the campus cultural aesthetic education function and the actual effect of ideological and political education}

With excellent campus culture to promote the development of the ideological and political education, enhance the actual effect of ideological and political education, an important aspect is to give full play to the excellent aesthetic education function of campus culture. Excellent campus culture is a necessary culture which reflects beauty, shows beauty, spreads beauty and has aesthetic value.

Ideological and political education and aesthetic education are two different education activities in the field of teaching, but both also have internal consistency, and the benign interaction can enhance the effectiveness of the education effect. Therefore, college ideological and 
political education workers should give full play to the excellent aesthetic education function of campus culture, to incorporate aesthetic education in ideological and political education, enrich the content of ideological and political education, and enhance the actual effect of ideological and political education ${ }^{[3]}$.

(1) Using vivid characteristics of aesthetic education to promote ideological and political education. Mainly manifested in the following two aspects: firstly, the ideological and political education workers set up their own image of beauty, including the thought of beauty, character beauty, language beauty, etc., make oneself become a role model for students learning, and improve the students accepting the self-consciousness of ideological and political education. Secondly, the modern multimedia technology should be fully used in the ideological and political theory class, which can show more image in front of students and make students deepen the understanding of ideological and political theory, master the abstract theory in a relaxed atmosphere.

(2) Using affective characteristics of aesthetic education to promote ideological and political education. Theoretical characteristics of ideological and political education is very strong. If the content of ideological and political education is the only empty dogma, people will tend to produce hate psychology. Therefore, ideological and political education workers can set the appropriate situation, adopt proper aesthetic form and content, make the osmosis aesthetic affective characteristics of the ideological and political education, pay attention to the use of affectionate language, bring students into a specific scene. Through its personal emotional experience caused its emotional resonance, so as to enhance the actual effect of ideological and political education. For example, in the patriotism education, the video, pictures and music can be fully used to set the patriotism. Teachers also can use the interpretation and analysis which is full of patriotic emotion to arouse the students patriotic emotion sympathetic chord, so as to achieve the effect which can not be got through the abstract empty moralistic education .
(3) Using potential characteristics of aesthetic education to promote ideological and political education. Through using various carriers of campus culture, the ideological and political education can be integrated into the campus culture. College students can unconsciously and subtly accept the ideological and political education, when they contact these carriers of campus culture. And excellent campus culture itself is a kind of potential education strength. Living in such a cultural environment for a long time, college students not only directly access to the emotional experience of beauty, but also indirectly get the ideological and political education in the emotional communication and edify. College students influenced by aesthetic edification of ideological and political education for a long time can form a kind of mental structure to pursuing the truth, honest and beauty. And if this kind of psychological structure is formed, finally a profound and lasting potential role affects the thought of the college students, make them form a good strong morals and thought quality.

\section{Conclusions}

With the reform deepening and the transformation of economic system in our country, the ideological and political education work is facing the new situation, new problems and new tasks of challenge. Changing the previous traditional way of ideological and political education is necessary.This paper discusses how to give full play to the aesthetic factors of campus culture in colleges to enhance the actual effect of ideological and political education, which can give a guidance for reforming the ideological and political education in colleges. 


\section{Acknowledgements}

This research is supported by The Projet of Hebei Social Development Research (QN:2015040409), and College Students' Innovative Entrepreneurial Project of Agricultural University of Hebei (QN:2015064)

\section{References}

[1] Jon R. Hufford, "Can the Library Contribute Value to the Campus Culture for Learning?", The Journal of Academic Librarianship, pp. 288-296, 2013.

[2] WEI Dong, XU Yun, “The Important Role Played by Ideological Education in the Construction of Campus Culture," Journal of Yichun College, pp. 49-50, 2010.

[3] Rong Yu, "The Research of How to Effective Implementation the Political Education in Employment Guidance for University Students," IERI Procedia, pp. 238-242, 2012. 